\title{
Ghrelin Gene Products in Acute and Chronic Inflammation
}

\author{
Flavia Prodam $\cdot$ Nicoletta Filigheddu
}

Received: 29 November 2013/Accepted: 21 March 2014/Published online: 12 April 2014

(C) L. Hirszfeld Institute of Immunology and Experimental Therapy, Wroclaw, Poland 2014

\begin{abstract}
Ghrelin gene products-the peptides ghrelin, unacylated ghrelin, and obestatin-have several actions on the immune system, opening new perspectives within neuroendocrinology, metabolism and inflammation. The aim of this review is to summarize the available evidence regarding the less known role of these peptides in the machinery of inflammation and autoimmunity, outlining some of their most promising therapeutic applications.
\end{abstract}

Keywords Acylated ghrelin · Unacylated ghrelin · Obestatin $\cdot$ Autoimmune disease $\cdot$ Inflammatory disease

$\begin{array}{ll}\begin{array}{l}\text { Abbreviations } \\ \text { ANCA }\end{array} & \begin{array}{l}\text { Anti-neutrophil cytoplasmic antibody } \\ \text { BMI }\end{array} \\ \text { COPD } & \begin{array}{l}\text { Chronic obstructive pulmonary } \\ \text { disease } \\ \text { [D-Lys3] Growth hormone releasing } \\ \text { peptide-6 }\end{array} \\ \text { [D-Lys3]-GHRP-6 } \\ \text { GH } & \begin{array}{l}\text { Growth hormone } \\ \text { Growth hormone secretagogue } \\ \text { receptor type 1a }\end{array} \\ \text { GHS-R1a } & \begin{array}{l}\text { Ghrelin } O \text {-acyltransferase } \\ \text { Glycogen synthase kinase }\end{array} \\ \text { GSK } & \text { Anti-insulin antibody } \\ \text { IA } & \text { Interleukin } \\ \text { IL } & \end{array}$

F. Prodam

Departmant of Health Sciences, Università del Piemonte

Orientale "Amedeo Avogadro", Novara, Italy

N. Filigheddu $(\bowtie)$

Department of Translational Medicine, Università del Piemonte Orientale "Amedeo Avogadro", Via Solaroli 17, 28100 Novara, Italy

e-mail: nicoletta.filigheddu@med.unipmn.it
LPS
MPTP
$\mathrm{NF}-\kappa \mathrm{B}$
TNF- $\alpha$
VCAM-1
Lipopolysaccharide
1-Methyl-4-phenyl-1,2,3,6-
tetrahydropyridine
Nuclear factor-kappaB
Tumor necrosis factor-alpha
Vascular cell adhesion molecule-1

\section{Introduction}

Ghrelin is a circulating acylated peptide that promotes a strong release of growth hormone $(\mathrm{GH})$ through binding to and activation of its receptor $\mathrm{GH}$ secretagogue receptor type 1a (GHS-R1a) in hypothalamus and pituitary (Kojima et al. 1999; van der Lely et al. 2004). In recent times, ghrelin gained popularity as the "hunger hormone" because its secretion, mainly from the stomach, is regulated by fasting and, in turn, it induces appetite, promotes adiposity, and controls energy homeostasis (Ariyasu et al. 2001; Tschöp et al. 2000; Wren et al. 2001). In humans, ghrelin secretion is pulsatile, with a higher secretion during the night. Plasma concentration of ghrelin rises during fasting, drops to basal values after the assumption of food, and it could contribute to meal initiation or choose of nutrients (Cummings 2006). Ghrelin is commonly altered in pathological conditions affecting body mass and/or body energy metabolism, negatively correlating with body mass index (BMI) (van der Lely et al. 2004). Ghrelin circulating levels are indeed lower in overweight or obese subjects than in normal individuals (Tschöp et al. 2000), with the exception of Prader Willi syndrome (Cummings et al. 2002), and higher in conditions characterized by energy inadequacy such as anorexia/cachexia associated with cancer (Garcia et al. 2005; Shimizu et al. 2003) and several 
other pathologies including chronic heart and renal failure, chronic obstructive pulmonary disease (COPD), and cystic fibrosis (Cohen et al. 2008; Itoh et al. 2004; Nagaya et al. 2001; Yoshimoto et al. 2002). Insulin and glucose are among the major determinants of ghrelin secretion that, in turn, modulates insulin secretion and glucose metabolism (van der Lely et al. 2004; Wiedmer et al. 2007). Recently, the specific acyltransferase that octanoylates ghrelin (GOAT: ghrelin $O$-acyltransferase) was detected in human circulation in healthy, obese, and anorexic adults with a positive correlation with BMI and a negative correlation with ghrelin levels (Goebel-Stengel et al. 2013).

Beside its role in feeding and energy homeostasis, ghrelin exerts also an extensive array of other biological activities such as cardio-protection and the enhancement of cardiac function (Baldanzi et al. 2002; Nagaya et al. 2004), pro-kinetic actions on gastric motility (Chen and Tsai 2012), and neuronal activities (Raimondo et al. 2013), including those on sleep (García-García et al. 2014), epilepsy (Portelli et al. 2012), and learning and memory (Beck and Pourié 2013).

The unique acylation of ghrelin on serine 3, mainly with octanoic acid, is essential for ghrelin activity through GHSR1a. Indeed, the unacylated form of ghrelin, which accounts for most of the circulating peptide, does not bind to and activate GHS-R1a (Kojima et al. 1999), unless used at micromolar concentrations, because at such high concentrations the unacylated form can act as a functional agonist (Bednarek et al. 2000; Gauna et al. 2007; Heppner et al. 2014; Matsumoto et al. 2001). However, starting with the first demonstration in vitro of the anti-apoptotic activity of unacylated ghrelin on cardiomyocytes and endothelial cells (Baldanzi et al. 2002), and, then, in vivo on insulin secretion in humans (Broglio et al. 2004), a continuously increasing number of works demonstrated that unacylated ghrelin is a biologically active peptide, sharing, often in cells lacking GHS-R1a, most of acylated ghrelin biological activities.

Among the wide range of common biological functions, acylated and unacylated ghrelin exert a protective activity on several cell lines including cardiac and endothelial cells, pancreatic $\beta$ cells, islets, and islet microendothelial cells, cortical neurons, vascular smooth muscle cells, and visceral adipocytes (Baldanzi et al. 2002; Chung et al. 2008; Favaro et al. 2012; Granata et al. 2007; Hwang et al. 2009; Rodríguez et al. 2012; Zhan et al. 2008). Both peptides promote the differentiation of skeletal myoblasts, preadipocytes, and embryonic stem cells toward cardiomyocytes (Filigheddu et al. 2007; Gao et al. 2012, 2013; Giovambattista et al. 2008; Miegueu et al. 2011). Moreover, they affect, either positively or negatively, proliferation of numerous cell types including osteoblasts, pancreatic $\beta$ cells, islets and islet microendothelial cells, myoblasts, and adrenocortical tumor cells (Delhanty et al. 2006, 2007; Favaro et al. 2012; Filigheddu et al. 2007; Granata et al. 2007).

Since unacylated ghrelin shares with ghrelin common high affinity binding sites in various cell lines, including cells lacking GHS-R1a (Baldanzi et al. 2002; Cassoni et al. 2001, 2004; Filigheddu et al. 2007; Granata et al. 2007; Jeffery et al. 2002; Muccioli et al. 2004), and they share biological activities in vivo, also in Ghsr null mice (Porporato et al. 2013), both peptides act in all probability through a common, although yet unidentified, receptor.

In some conditions, however, unacylated ghrelin counteracts ghrelin activities both in vitro and in vivo (Benso et al. 2012; Broglio et al. 2004, 2008; Gauna et al. 2005), suggesting a complex interplay between the two forms of the peptide. Unacylated ghrelin participates also in the regulation of food intake and adipogenesis through mechanisms not fully elucidated, but very likely independent of GHS-R1a (Asakawa et al. 2005; Inhoff et al. 2008; Toshinai et al. 2006).

The processing of the 117 aa peptide encoded by the ghrelin gene results, in addition to acylated and unacylated ghrelin, in a 23 aa peptide named "obestatin" for its supposed anti-obesity activity achieved by contrasting ghrelin effects through the binding to GPR39 receptor (Zhang et al. 2005). Successive works, however, did not support these assertions (Bassil et al. 2007; Chartrel et al. 2007; Lauwers et al. 2006), and the biological role of obestatin is still debated (Lacquaniti et al. 2011). Nevertheless, obestatin has several biological activities, including protective effects on the cardiovascular system (Agnew et al. 2012; Alloatti et al. 2010; Aragno et al. 2012), promotion of adipocytes survival, differentiation, and metabolism (Granata et al. 2012; Gurriarán-Rodríguez et al. 2011; Miegueu et al. 2011; Pruszynska-Oszmalek et al. 2013), induction of myoblasts differentiation and promotion of skeletal muscle regeneration (Gurriarán-Rodríguez et al. 2012), inhibition of pancreatic $\beta$-cell and islets apoptosis, stimulation of glucose-stimulated insulin secretion in both normal and diabetic animal models, and enhancement of functional $\beta$ cell generation from pancreatic precursor cells (Baragli et al. 2013; Granata et al. 2008, 2010). Notably by an evolutionary point of view, while ghrelin is mainly involved in food intake, obestatin has an inhibitory effect on water drinking by acting on mechanisms involved in the thirst (Samson et al. 2007) and decreases vasopressin concentration in plasma (Samson et al. 2008).

Circulating obestatin concentrations have been reported to be either reduced (Anderwald-Stadler et al. 2007; Nakahara et al. 2008) or, more frequently, increased (Guo et al. 2007; Prodam et al. 2011; Reinehr et al. 2008; Vicennati et al. 2007) in obesity. Based on available data, it is difficult to explain these contrasting findings that seem to 
depend mainly on sample size, age, and ethnicities. Obestatin is also regulated by fasting and food intake, although with different kinetics with respect to acylated and unacylated ghrelin (Guo et al. 2008; Prodam et al. 2011). It is partially refractory to the inhibition by the exogenous administration of insulin (Anderwald-Stadler et al. 2007), as also to the physiological increase in insulin at the glucose challenge (Prodam et al. 2011).

\section{Ghrelin and GHS-R1a mRNA Expression and Distribution in the Lymphoid System}

Real-time PCR analysis revealed the expression of ghrelin mRNA in human T cells (Dixit et al. 2004; Hattori et al. 2001), B cells, neutrophils, macrophages, monocytes, dendritic cells, natural killer cells, and several leukemic cell lines (Baatar et al. 2011; Delgado and Ganea 2008; Dixit et al. 2004; Hattori et al. 2001). In addition, when activated, $\mathrm{T}$ cells also express the preproghrelin protein and produce and secrete both acylated and unacylated ghrelin (Baatar et al. 2011; Dixit et al. 2004). Besides lymphocytes, ghrelin mRNA was also found in human spleen, lymph nodes, and thymus (Dixit et al. 2004; Gnanapavan et al. 2002). In thymus, ghrelin and the GHS-R1a decline with age. Ghrelin seems to be a novel regulator of epithelial-to-mesenchymal transition and preserves thymic stromal cell microenvironment by controlling age-related adipocytes development within the thymus (Youm et al. 2009).

Also GHS-R1a is widely expressed in the lymphoid system, and its expression was reported in the same cells expressing ghrelin (Dixit et al. 2004; Hattori et al. 2001), as well as in the spleen (Gnanapavan et al. 2002). A truncated inactive GHS-R1b has been shown in various immune tissues, although ghrelin does not bind to and activate it and the role of this receptor is still unknown (Taub 2008). Expression of ghrelin and GHS-R1a was detectable in all immune cells regardless of the maturity and cell types with huge variations due to inter-individual changes and to the activation state of the cells being examined (Baatar et al. 2011; Hattori et al. 2001).

Activation of $\mathrm{T}$ cells results in the increase in the GHSR1a expression and its localization at the plasma membrane in lipid rafts. The same localization of endogenous ghrelin upon $\mathrm{T}$ cell activation suggests its possible autocrine/paracrine function in immune cells (Dixit et al. 2004).

The wide expression of ghrelin and GHS-R1a in the lymphoid system strongly suggests a role for this peptide and its receptor in the regulation of the immune system activity, but ghrelin activity could be even wider than suspected. [D-Lys3]-GHRP-6 is a synthetic peptide used in vitro and in vivo as a selective GHS-R1a antagonist, despite the fact that in some conditions it acts as a functional agonist of the GHS-R1a (Depoortere et al. 2006; Erriquez et al. 2009), and in others it is not able to counteract the endocrine functions of ghrelin (Benso et al. 2007). Recently, [D-Lys3]-GHRP-6 has been shown to act as antagonist on the CXCR4 and CCR5 chemokine receptors in $\mathrm{T}$ cells and peripheral blood mononuclear cells (Patel et al. 2012a, b). However, no data are still available on ghrelin activity on these receptors. Notably, GHS-R1a is activated also by another neuropeptide, cortistatin, which, although encoded by a different gene, shares high homology with somatostatin and binds to all the known somatostatin receptor subtypes with similar affinity and to MrgX2, a previously orphan G-protein-coupled receptor expressed in the dorsal root ganglions. The binding to GHS-R1a and to MrgX2 is highly specific for cortistatin, being somatostatin devoid of it (de Lecea and Castaño 2006). The ability of cortistatin to bind to GHS-R1a is particularly intriguing, since somatostatin and its fragments do not bind all the same receptor (de Lecea and Castaño 2006). Human immune cells produce cortistatin but not somatostatin. Macrophage lineage, activated endothelium, human lymphocytes and thymus express several somatostatin receptor subtypes and the MrgX2 receptor (van Hagen et al. 2008), suggesting that cortistatin might represent the link between ghrelin and the somatostatin/ cortistatin system in the immune system.

\section{Ghrelin, Unacylated Ghrelin, and Obestatin Secretion and Activity in Acute and Chronic Inflammatory States}

Several studies on the anti-inflammatory activity of ghrelin showed that only the acylated peptide was able to decrease the expression and production of proinflammatory cytokines: interleukin (IL)-1 $\alpha$, IL-1 $\beta$, IL-6, and tumor necrosis factor (TNF)- $\alpha$ by activated $\mathrm{T}$ cells and by lipopolysaccharide (LPS)-activated monocytes and microglia (Dixit et al. 2004; Li et al. 2004; Theil et al. 2009). Ghrelin has been shown to prevent also microglial activation in a mouse model of Parkinson's disease by inhibiting the expression of TNF- $\alpha$ and IL- $1 \beta$ induced by administration of 1-methyl-4-phenyl-1,2,3,6-tetrahydropyridine (MPTP) and to prevent the release of TNF- $\alpha$ and IL-1 $\beta$ from microglia treated with threohydroxyaspartate (Lee et al. 2012; Moon et al. 2009). Since GHS-R1a is not expressed in microglial cells, this effect of ghrelin on microglia activation might be either indirect or could be mediated by a yet unknown receptor. Experiments carried out in vitro on N9 microglia cells, which do not express GHS-R1a, produced quite different results, since only unacylated ghrelin, but not acylated ghrelin, was able to impair the 
expression of IL-1 $\beta$, IL-6 induced by exposure to fibrillar beta-amyloid protein (Bulgarelli et al. 2009).

The effect of ghrelin on pro-inflammatory cytokines induction and release has been related, in several studies, to a suppression of the expression and/or activity of the transcription factor NF- $\kappa \mathrm{B}$ (Barazzoni et al. 2014; Hou et al. 2009; Konturek et al. 2006; Li et al. 2004; Liu et al. 2010; Peng et al. 2012; Slomiany and Slomiany 2013; Wang et al. 2012; Waseem et al. 2008; Wu et al. 2005; Yuan et al. 2009; Zhou and Xue 2009). However, it has been proposed that in some circumstances and with some cell types, ghrelin may act as a pro-inflammatory peptide inducing, rather than reducing, NF- $\mathrm{\kappa B}$ expression and proinflammatory IL-8 secretion (Kwan et al. 2010; Rezaeian et al. 2012; Sung et al. 2011; Zhao et al. 2006). Also the vagus nerve seems to play a central role in ghrelin-mediated inhibition of proinflammatory cytokine release (Cheyuo et al. 2011; Wu et al. 2007a, 2008, 2009) and that anti-inflammatory activity of vagal stimulation is ghrelinmediated (Bansal et al. 2012).

Although unacylated ghrelin is not able to induce the same effects of the acylated peptide in activated T cells and endothelial cells, (Dixit et al. 2004; Li et al. 2004), nevertheless it impairs TNF- $\alpha$ induction in muscles and livers of rats undergoing burn injury and reduces, in myotubes in vitro, the activation of NF- $\mathrm{KB}$ induced by treatment with pro-inflammatory cytokines (Sheriff et al. 2012).

Also obestatin has been shown to reduce circulating levels of TNF- $\alpha$ and to impair NF- $\kappa B$ translocation in left ventricular tissue of diabetic rats (Aragno et al. 2012).

These observations suggest that ghrelin gene products may have a role in both acute and chronic inflammatory states, and this hypothesis is further supported by the observation that circulating levels of these peptides are often altered in inflammatory states (Table 1). Inflammation is a major player in many acute and chronic diseases, first of all obesity, which is characterized by a chronic subtle inflammatory state. On the other hand, obesity affects the immune response, leading to an increased susceptibility to infections and some infectious agents may have an etiological role in obesity, an idea known as "infectobesity" (Genoni et al. 2014).

Ghrelin physiologically binds to plasma immunoglobulins (Ig) and conditions of altered nutrition affect the affinity of ghrelin for IgG. In particular, it has been suggested that plasma ghrelin-reactive IgG auto-antibodies serve as carrier proteins that might enhance the bioactivity of ghrelin, thus explaining the phenomenon of enhanced

Table 1 Ghrelin, unacylated ghrelin, and obestatin concentrations in acute and chronic inflammatory states and in autoimmune diseases in humans

\begin{tabular}{|c|c|c|c|c|}
\hline Conditions & Total ghrelin & Acylated ghrelin & Unacylated ghrelin & Obestatin \\
\hline \multicolumn{5}{|c|}{ Acute and chronic inflammatory states } \\
\hline Cachexia & $\uparrow$ & $\uparrow$ & nd & nd \\
\hline \multirow[t]{2}{*}{ Sepsis } & $\uparrow$ & nd & nd & nd \\
\hline & $\uparrow$ after LPS administration & & & \\
\hline Cystic fibrosis & $\uparrow$ & $\uparrow$ & nd & nd \\
\hline Atherosclerosis & $\downarrow$ & nd & $\downarrow$ & nd \\
\hline Alzheimer's disease & - & nd & nd & nd \\
\hline Uveitis & nd & nd & nd & nd \\
\hline \multicolumn{5}{|l|}{ Autoimmune diseases } \\
\hline \multirow[t]{2}{*}{ Multiple sclerosis } & $\uparrow$ & nd & $\uparrow$ & nd \\
\hline & & & $\uparrow$ (in CSF) & \\
\hline Rheumatoid arthritis & - & - & nd & - \\
\hline ANCA vasculitis & $\uparrow$ & nd & nd & nd \\
\hline \multirow[t]{2}{*}{ Type 1 diabetes } & $\downarrow$ at the onset & $\downarrow$ at the onset & $\downarrow$ & $\uparrow$ \\
\hline & $\downarrow$ or - after insulin & $\downarrow$ or - after insulin & & \\
\hline \multirow[t]{2}{*}{ Thyroiditis } & $\uparrow$ or - in hypothyroidism & $\downarrow$ in hyperthyroidism & nd & $\uparrow$ or - in hypothyroidism \\
\hline & $\downarrow$ in hyperthyroidism & & & $\downarrow$ in hyperthyroidism \\
\hline \multirow[t]{2}{*}{ Atrophic gastritis } & $\downarrow$ & nd & nd & nd \\
\hline & - & & & \\
\hline \multirow[t]{2}{*}{ Celiac disease } & $\uparrow$ at the diagnosis & nd & nd & nd \\
\hline & - during GFD & & & \\
\hline IBD & $\uparrow$ & $\uparrow$ & nd & nd \\
\hline
\end{tabular}

$C S F$ cerebrospinal fluid, GFD gluten-free diet, IBD inflammatory bowel diseases, $L P S$ lipopolysaccharide, $n d$ : not determined 
orexigenic activity of ghrelin in obesity (Takagi et al. 2013). On the other hand, in anorexia nervosa, these IgG auto-antibodies exist mainly as immune complexes with unacylated ghrelin, leading to a decrease in a free fraction of these auto-antibodies binding acylated and unacylated ghrelin (Terashi et al. 2011) and this may explain the decreased orexigenic effects of ghrelin in this pathology.

Because of the well-known role of ghrelin in feeding and energy homeostasis, many reviews discuss its role with respect to obesity (Prodam et al. 2008; Wiedmer et al. 2007). Therefore, we will discuss other aspects of the regulation and action of ghrelin in inflammatory conditions other than obesity. Moreover, more recently some evidences suggest that unacylated ghrelin may have a therapeutic role in obesity and type 2 diabetes comorbidities. It has been shown that a treatment with both unacylated ghrelin and an analog of it prevented in a murine pre-diabetes model the proinflammatory effects elicited by a high-fat diet. This effect was coupled with an expression of mitochondrial function markers in brown adipose tissue, and with prevention of development of the pre-diabetic metabolic state (Delhanty et al. 2013). Furthermore, systemic administration of unacylated ghrelin prevented diabetes-induced damage of endothelial progenitor cells and facilitated their mobilization from bone marrow (Togliatto et al. 2010).

\section{Cachexia}

Cachexia is a multifactorial syndrome, associated with various pathological conditions, and characterized by severe weight loss, muscle and adipose tissue wasting, and inflammation. Ghrelin circulating concentrations are increased in pathological conditions characterized by cachexia, including chronic heart failure, COPD, and different types of cancer (Garcia et al. 2005; Itoh et al. 2004; Kerem et al. 2008; Nagaya et al. 2001; Shimizu et al. 2003). Regardless of the underlying disease, this cachexiaassociated hyperghrelinemia may represent either a compensatory mechanism to the negative energy balance and the inflammatory state or the development of a resistance to the ghrelin signaling. This latter hypothesis is supported by the finding that in tumor-bearing cachectic mice the orexigenic effect of ghrelin is reduced compared to noncachectic littermates (Wang et al. 2006).

\section{Sepsis}

Sepsis, the systemic inflammatory response to an infection, may be associated with dysfunctions of several organs, including heart, kidneys, liver, and lungs. Several studies, both in animal models and humans, have demonstrated that sepsis modulates plasmatic ghrelin concentrations and that the administration of ghrelin has beneficial effects on sepsis. In surgical patients with postoperative intraabdominal sepsis plasma levels of ghrelin increased and positively correlated with TNF- $\alpha$ and IL-6 levels (Maruna et al. 2005). In healthy human subjects, LPS administration induced a biphasic change in circulating ghrelin levels, with a rapid increase reaching the maximum after the pick of TNF- $\alpha$ and a subsequent decrease with the nadir $5 \mathrm{~h}$ after LPS administration (Vila et al. 2007). In rodent models of sepsis, induced either by LPS injection or caecal ligation and perforation, ghrelin treatment reduced the level of pro-inflammatory cytokines both in circulation and in tissues impacted by sepsis, such as lung and kidney (Peng et al. 2012; Wang et al. 2009; Wu et al. 2007b). It has been shown that ghrelin protective effects are mediated by the activation of the vagal nerve (Wu et al. 2007a), inhibition of sympathetic nervous system, seen as reduced gut-derived norepinephrine release (Jacob et al. 2010; Wu et al. 2007c), and inhibition of NF- $\kappa$ B pathway (Peng et al. 2012; Wu et al. 2007b). In addition, ghrelin exerts its protective action through inhibition of high-mobility group box release (Chorny et al. 2008; Wu et al. 2009) and through an antimicrobial activity (Chorny et al. 2008).

\section{Cystic Fibrosis}

Cystic fibrosis is a genetic disease that arises from mutations in the cystic fibrosis transmembrane conductance regulator gene, which cause a dysfunction of chloride channels. Chronic cachexia and refractory chronic respiratory infections are typical features of the disease. Three week intravenous ghrelin administration suppressed airway inflammation through a decrease in neutrophil titer in lungs of cachectic patients with chronic respiratory infections (Kodama et al. 2008). Regarding the specific regulation of the ghrelin system in cystic fibrosis, total and acylated ghrelin levels were higher in patients in agreement with their cachectic condition (Cohen et al. 2008; Monajemzadeh et al. 2013). GHS-R1a expression decreases in lymphocytes from cachectic cystic fibrosis patients with acute exacerbation. This may only partially be explained as a down-regulation in response to the observed increase in ghrelin circulating levels, since, after antibiotic treatment, GHS-R1a expression in lymphocytes returned to baseline, while ghrelin levels remained increased (Cohen et al. 2010).

\section{Atherosclerosis}

Atherosclerosis is a chronic inflammatory disease characterized by thickening and hardening of vessels due to accumulation of lipids. Macrophages play a major role in the development of atherosclerosis, accumulating cholesterol through an increased uptake of oxidized low-density lipoproteins that leads to foam cell formation. 
The alteration of circulating levels of acylated and unacylated ghrelin in some typology of patients (Kotani et al. 2006; Pöykkö et al. 2006; Yano et al. 2009) and the increase in radiolabeled ghrelin binding in the atherosclerotic cardiovascular system (Katugampola et al. 2001) strongly suggest a role of ghrelin gene products in this pathology.

Although the anti-inflammatory activity of ghrelin may at once suggest an anti-atherosclerotic activity, the role of this peptide in the development and progression of atherosclerosis appears actually quite controversial. Ghrelin increases the efflux of cholesterol from macrophages through regulation of peroxisome proliferator-activated receptor $\gamma$, thus inhibiting the formation of foam cells and reducing the development of atherosclerotic lesions (Cheng et al. 2010; Demers et al. 2009). In TNF- $\alpha$-treated human endothelial cells, ghrelin inhibits proinflammatory cytokine production, NF- $\kappa \mathrm{B}$ activation, expression of adhesion molecules, and adhesion of monocytes (Kellokoski et al. 2009; Li et al. 2004). Diversely, without TNF- $\alpha$ stimulation, ghrelin shows a pro-atherogenic activity (Kellokoski et al. 2009; Skilton et al. 2005). Finally, mice lacking both ghrelin receptor and low-density lipoprotein receptor fed with a high-fat, high-cholesterol diet show no differences in atherosclerotic plaque progression compared with their controls, suggesting that Ghsr is not involved in the plaque development and/or progression (Habegger et al. 2011). However, this does not exclude that at least some of the observed effects of ghrelin on atherosclerosis may be mediated by the alternative, yet unknown ghrelin receptor.

Obestatin reduces adhesion molecule VCAM-1 expression and oxidized low-density lipoprotein binding to macrophages, an early step in foam cells formation (Kellokoski et al. 2009). Moreover, decreased levels of obestatin in subjects with metabolic syndrome associate with an increased carotid atherosclerosis (Cui et al. 2012).

Although it has been suggested that unacylated ghrelin may represent a cardiometabolic marker for predicting atherosclerosis in elderly hypertensive subjects, where its circulating levels are altered and inversely correlated with atherosclerosis markers as carotid intima media thickness (Yano et al. 2009), no in vitro studies have been performed to investigate a possible role for this peptide in the development and/or progression of the pathology.

\section{Alzheimer's Disease}

Alzheimer's disease is a neurodegenerative disorder characterized by an early hippocampal damage. The pathogenesis is still unknown, although it is well known that the accumulation of amyloid- $\beta$ peptide and the following chronic microglia inflammation exert a crucial role. Also insulin resistance and the GH/IGF-I system have a functional role in the development of the disease. Because many reports show that ghrelin is involved in neuroprotection, learning, and memory, the assumption of a role in Alzheimer's disease is fairly justified. First of all, ghrelin, GOAT, and GHS-R1a are all down-regulated in the temporal gyrus, one of the most compromised cortical regions in Alzheimer's disease (Gahete et al. 2010). This pattern was associated with a shift in the GHS-R1a/GHS-R1b ratio, suggesting an impairment of the autocrine/paracrine mechanisms (Gahete et al. 2010). Conversely, ghrelin increases insulin-stimulated neuronal glucose uptake, decreases insulin resistance, and altered tau phosphorylation via the PI3-K/Akt-GSK pathway in hippocampal neuron cultures (Chen et al. 2010), suggesting that it may represent a potential treatment. Indeed, in murine models of the disease, treatments with ghrelin or GHS-R1a agonists reduced the levels of amyloid- $\beta$ peptide and inflammation of the microglia (Dhurandhar et al. 2013; Moon et al. 2011). In particular, ghrelin decreases the production of superoxides, mitochondrial membrane depolarization induced by amyloid- $\beta$ oligomers and prevents GSK-3 $\beta$ activation (Martins et al. 2013). Amyloid- $\beta$ peptides are able to bind to CD36, a multifunctional protein that is a type B scavenger receptor and that possesses binding sites for the synthetic GHS, like hexarelin (Demers et al. 2004). Hexarelin and unacylated ghrelin, but not acylated ghrelin, seem to interfere with amyloid- $\beta$ peptide activation of CD36 in microglia cells (Bulgarelli et al. 2009), suggesting that the protective role of the ghrelin system in Alzheimer's disease may occur, at least in part, in a GHS-R1a independent manner. Interestingly, it has been recently shown that semagacestat, a $\gamma$-secretase inhibitor, which belongs to the therapeutic agents for Alzheimer's disease, is able to activate the GHS-R1a alone or in synergy with acylated ghrelin itself (Schellekens et al. 2013). Because only a few data have been published in patients with Alzheimer's disease and reported unchanged ghrelin levels in both plasma and cerebrospinal fluid with respect to age-matched controls (Proto et al. 2006; Theodoropoulou et al. 2012), more efforts are needed to better characterize the physiology of the ghrelin system in this condition.

\section{Uveitis}

Uveitis is an inflammatory disease of the uveal tract including the iris, ciliary body, and choroidea. It can cause permanent damages in ocular tissues, and sometimes visual loss. Its pathogenesis is still unknown, but several cytokines are involved, among the others IL-1, IL-6, and TNF$\alpha$ that can be detected in ocular fluids of patients. Because of the anti-inflammatory activity of ghrelin and the presence of ghrelin and GHS-R mRNA in rat and human eyes 
(Azevedo-Pinto et al. 2013), some authors investigated if ghrelin administration could be beneficial for the treatment of uveitis. However, the intraperitoneal administration of ghrelin at the dose of $10 \mathrm{ng} / \mathrm{kg} /$ day for one week, diversely from tacrolimus or infliximab, failed to reduce IL-1, IL-6, and TNF- $\alpha$ in the vitreous of a rat model of uveitis (Gül et al. 2013; Turgut et al. 2013). However, this could be due to an improper route of administration or to a too low dose.

\section{Ghrelin, Unacylated Ghrelin, and Obestatin Secretion and Activity in Autoimmune Diseases}

\section{Multiple Sclerosis}

Multiple sclerosis is an autoimmune inflammatory disease characterized by the progressive loss of axons myelination, leading to an altered transmission of nerve signals. Patients, both relapsing-remitting and progressive, have significantly higher circulating levels of total ghrelin than healthy subjects (Berilgen et al. 2005), and a more recent study showed a significant increase in unacylated ghrelin in cerebrospinal fluid that correlated with serum concentrations in patients but not in healthy controls (Unger et al. 2013). These findings suggest that ghrelin may affect the central inflammatory process in multiple sclerosis. Moreover, an association of a haplotype in the GHS-R gene with multiple sclerosis has been reported in some but not all cohorts of patients (Rey et al. 2011), suggesting that the system should be more studied in this disease in the future. Furthermore, in mouse experimental autoimmune encephalomyelitis, a model of multiple sclerosis, sc ghrelin administration was followed by a reduced clinical severity of the disease. This effect was coupled with reduced mRNA levels of proinflammatory cytokines (TNF- $\alpha$, IL$1 \beta$, IL-6) in the spinal cord cellular infiltrates and microglia (Theil et al. 2009). In addition, the ability of ghrelin to decrease the presence and the activation of encephalitogenic $\mathrm{T}$ helper 1 (Th1) and Th17 cells in periphery and nervous system and to induce regulatory $\mathrm{T}$ cells reinforces the idea of ghrelin as a promising agent to arrest or slow the progression of this disease (Souza-Moreira et al. 2013).

\section{Inflammatory Rheumatic Diseases}

Rheumatoid arthritis is a chronic inflammation of the musculoskeletal system, in which TNF- $\alpha$ is the main cytokine involved. Total and acylated ghrelin are similar to controls in adult patients with the disease, whereas interestingly, obestatin correlated with some inflammatory markers, in particular TNF- $\alpha$ and IL-6 (Koca et al. 2008). In agreement with these findings, increased circulating ghrelin levels and higher mRNA expression in the arcuate nucleus were recorded in rats with adjuvant arthritis, which is similar to human rheumatoid arthritis (Skurlova et al. 2010; Stofkova et al. 2009). Higher ghrelin levels were also reported in ANCA-associated vasculitis with a direct association with the severity of the disease (Kümpers et al. 2008).

Long-term treatments with $\mathrm{TNF}-\alpha$ inhibitors increased (Gonzalez-Gay et al. 2008) or did not change ghrelin secretion (Toussirot et al. 2013) irrespectively of a significant gain in fat mass or of the presence of metabolic syndrome in patients with rheumatoid arthritis or ankylosing spondylitis. A similar increase after treatment with TNF- $\alpha$ inhibitors was demonstrated also in juvenile idiopathic arthritis (Karagiozoglou-Lampoudi et al. 2011). On the other hand, a transient decrease in total and acylated ghrelin levels in the short-term treatment has been recorded (Chen et al. 2013; Magiera et al. 2013). It can be speculated that a functional hyperghrelinemia, insensitive to the regulation of the fat mass accrual, is a specific characteristic of these inflammatory diseases.

\section{Autoimmune Endocrine Diseases}

\section{Type 1 Diabetes}

Autoimmune-mediated destruction of $\beta$ cells causes type 1 diabetes and a decrease in $\beta$-cell mass. Most studies reported lower total and acylated ghrelin levels at the onset of the disease (Ashraf et al. 2007; Soriano-Guillén et al. 2004; Holdstock et al. 2004; Martos-Moreno et al. 2006), with a partial recovery of acylated ghrelin levels (MartosMoreno et al. 2006) and total ghrelin levels in some (Bideci et al. 2005; Holdstock et al. 2004) but not all studies (Ashraf et al. 2007; Celi et al. 2005; Huml et al. 2011; Soriano-Guillén et al. 2004) after a short-term insulin treatment. It has been demonstrated that insulin is essential for meal-induced suppression of ghrelin in adults with type 1 diabetes (Murdolo et al. 2003). Other studies observed a negative correlation between total or acylated ghrelin levels and mean daily insulin dosage in children and adolescents with type 1 diabetes, suggesting that insulin is one of the main regulators of ghrelin secretion in type 1 diabetes (Bideci et al. 2005; Celi et al. 2005; Huml et al. 2011). Because acylated ghrelin is similar to controls after the starting of insulin regimen and higher ghrelin levels are reported in streptozotocin-induced diabetic rats (Dong et al. 2006; Gelling et al. 2004), this suggests that in type 1 diabetes ghrelin is partially refractory to the inhibition by insulin. This finding is in agreement with the hypothesis of the involvement of acylated ghrelin in the hyperphagia and weight gain of type 1 diabetes after the onset of the disease. It has been reported that exogenous administration of acylated ghrelin ameliorates glucose metabolism in a 
neonate streptozotocin-induced diabetic rat model through enhancement of cell proliferation (Irako et al. 2006) and protective effects against the pro-oxidant damage of diabetes (Turk et al. 2012). In a rat model in which ghrelin and GOAT genes are overexpressed in pancreatic $\beta$ cells under the control of the rat insulin II promoter, the serum insulin levels, pancreatic insulin mRNA expression, and $\beta$-cell numbers in islets are increased (Bando et al. 2013), suggesting that acylated ghrelin can directly stimulate $\beta$-cell proliferation in vivo after islet injury even without its orexigenic or GH-stimulating activities. In other studies, both acylated and unacylated ghrelin prevent apoptosis in the $\beta$-cell lines HIT-T15 and INS-1E, as well as in human islets (Granata et al. 2007). Similarly, obestatin prevents $\beta$ cell apoptosis, preserves $\beta$-cell mass, and stimulates insulin secretion in vitro and in vivo in animals, in both normal and diabetic conditions (Egido et al. 2009; Granata et al. 2008, 2012). More recently, it has been observed that obestatin promotes the generation of islet-like cell clusters with increased insulin gene expression and C-peptide secretion (Baragli et al. 2013).

Mechanisms involved in a putative loop between autoimmunity machinery in the pancreas and the preproghrelinderived peptides are still unexplored. However, administration of acylated ghrelin increased anti-insulin antibody (IA)- $2 \beta$ mRNA but not that of IA-2, another structurally related $\beta$-cell autoantigen in mouse brain, pancreas, and insulinoma cell lines (MIN6 and $\beta$ TC3) (Doi et al. 2006). We observed that obestatin levels were negatively associated with C-peptide and IA levels at the onset of type 1 diabetes in a cohort of children with type 1 diabetes, advancing an interesting role in pancreas regulation in this condition (Prodam et al. 2014).

\section{Autoimmune Thyroiditis}

Follicular thyroid tissue of patients with Hashimoto's thyroiditis produces ghrelin and obestatin at similar levels as in normal thyroid tissue (Bossowski et al. 2013; Karaoglu et al. 2009). Ghrelin also immunocolocalizes with calcitonin in normal $\mathrm{C}$ cells of different mammals (Utrilla et al. 2013), and C cells are also able to secrete ghrelin (Morillo-Bernal et al. 2011). GHS-R1a and GPR39, the discussed receptor of obestatin, have been detected more in thyroid tissues of patients with Graves' disease than in those with non-toxic or toxic nodular goiter (Bossowski et al. 2013). Several data, often contrasting, reported ghrelin secretion in condition of hypo- and hyperthyroidism due to autoimmune and non-autoimmune diseases in humans. In the majority of the papers, ghrelin and obestatin are increased or unchanged in hypothyroidism, while they are lower or quite undetectable in hyperthyroidism. Thyroid substitution or tionamide treatment restores normal circulating levels (Bossowski et al. 2013). No correlations were observed between total ghrelin levels and antithyroid antibodies or human $\mathrm{C}$ reactive protein in children with untreated hyperthyroidism and subclinical hypothyroidism from Graves' disease and Hashimoto's thyroiditis, respectively (Sawicka et al. 2010). Conversely, total ghrelin levels were decreased in hypothyroid adults with high thyroid peroxidase antibody titer compared to hypothyroid patients with low thyroid peroxidase antibody with a negative correlation with age, thyroglobulin antibody, and thyroid peroxidase antibody titer (Altinova et al. 2006). In agreement with these findings, it is interesting to note that acylated ghrelin potentiates thyroid-stimulating hormoneinduced expression of the thyroid tissue-specific genes thyroglobulin, thyroperoxidase, and sodium-iodine symporter in rat PC-Cl3 cells (Morillo-Bernal et al. 2011).

\section{Autoimmune Gastrointestinal Diseases}

\section{Autoimmune Atrophic Gastritis}

The majority of the studies on atrophic gastritis have been focused on the pathological condition due to a Helicobacter pylori infection. Only two studies have focused on atrophic gastritis due to the presence of parietal cell antibodies with contrasting results. The first one was conducted in a wide cohort of adults and reported lower circulating ghrelin levels in patients positive to parietal cell antibodies with a negative correlation between ghrelin and gastrin levels (Checchi et al. 2007). The second one was conducted in a small cohort of subjects affected by type 1 diabetes with or without atrophic gastritis. They observed that ghrelin secretion was lower in subjects with type 1 diabetes without a gastric disease, and conversely, ghrelin levels were similar to controls when an autoimmune atrophic gastritis is present at the same time, suggesting a compensatory ghrelin synthesis in neuroendocrine cell hyperplasia lesions of gastric mucosa (Alonso et al. 2007).

\section{Celiac Disease}

Celiac disease is one of the most prevalent and incident autoimmune diseases in the last years. It is characterized by malabsorption, weight loss, and increased energy expenditure. Higher total ghrelin circulating levels were recorded in children and adults with newly diagnosed celiac disease (Lanzini et al. 2006; Peracchi et al. 2003; Selimoglu et al. 2006) with a direct correlation with the degree of severity of intestinal mucosal lesions (Peracchi et al. 2003; Selimoglu et al. 2006). Patients recovered normal ghrelin levels after two years of gluten-free diet (Capristo et al. 2005; Lanzini et al. 2006). Accordingly, the mean number of ghrelin-positive cells/field in gastric and distal duodenal 
mucosa specimens was higher in celiac patients than controls and normalized after the gluten-free diet (JarockaCyrta et al. 2010; Rocco et al. 2008). Many mechanisms have been advocated, including nutritional factors, functional responses to anorexia, malabsorption, and chronic inflammation. The role of higher ghrelin levels as a functional response to protect gut cells is supported by evidence that ghrelin administration protects against ischemia/ reperfusion by reducing ulceration, tissue congestion, cellular infiltration, and vascular permeability (El Eter et al. 2007; Wu et al. 2009). In particular, ghrelin inhibits reactive oxygen species generation by human polymorphonuclear cells in a dose-dependent manner (El Eter et al. 2007). Interestingly, ghrelin administration is followed by an increased activity of stomach catalase, superoxide dismutase, glutathione reductase, and glutathione peroxidase in newborn streptozotocin-induced diabetic rats (Coskun et al. 2013).

\section{Inflammatory Bowel Disease}

Crohn's disease is a chronic debilitating disease characterized by severe inflammation of the gastrointestinal tract. Th1 cells drive the inflammation of the colon. Patients with an active Crohn's disease have higher total and acylated ghrelin levels than those in remission with similar obestatin levels and a higher ghrelin to obestatin ratio (Alexandridis et al. 2009; Karmiris et al. 2006). Similar data have been reported in ulcerative colitis and high levels of ghrelin correlate with the severity of disease and the activity markers (Ates et al. 2008; Karmiris et al. 2006). Infliximab increased circulating total ghrelin in a small group of patient with Crohn's disease (Sung et al. 2009). Ghrelin mRNA levels in colonic mucosa of patients with inflammatory bowel diseases (Crohn's disease and ulcerative colitis) were higher than in controls. The GHS-R mRNA level in colon and the percentage of peripheral blood $\mathrm{T}$ cells positive to this receptor in active Crohn's disease, but not in ulcerative colitis, were also higher. However, lymphocyte reactivity to ghrelin was low in Crohn's disease, suggesting that ghrelin might participate in its pathogenesis (Hosomi et al. 2008). Ghrelin administration abrogates the intestinal inflammatory response and restores mucosal immune tolerance in a mouse model of colitis down-regulating Th1-driven autoimmune response (Gonzalez-Rey et al. 2006). Both ghrelin and obestatin, although through different mechanisms, inhibit the inflammation and induce anti-inflammatory cytokines in a rat model of acute and chronic colitis caused by oral administration of dextran sulfate sodium (Pamukcu et al. 2013). In particular, in the acute state the administration of both peptides resulted in reduced lipid peroxidation and Th1 cells. In the chronic state, both ghrelin and obestatin decreased IL-1 $\beta$, IFN- $\gamma$,
TNF- $\alpha$, but ghrelin increased TGF- $\beta$ without affecting IL10 , while obestatin increased colonic levels of IL-10 and TGF- $\beta$ (Pamukcu et al. 2013). Similar anti-inflammatory properties of ghrelin have been recorded in gut ischemia/ reperfusion models, which require an intact vagus to maintain the beneficial effects of the hormone ( $\mathrm{Wu}$ et al. 2009). These findings suggest that ghrelin attenuates inflammation and reduces injury through the modulation of the vagal cholinergic anti-inflammatory pathway. However, in contrast to the previous study, it has been demonstrated in a rodent colitis model, that ghrelin treatment enhanced clinical disease activity and promoted the infiltration of neutrophils and colonic IL-1 $\beta$ levels (De Smet et al. 2009). These results could depend on route and dosage of the peptide administration, as well as on the age of animals, and strongly suggest to be cautious in further studies, because without further clarifying the physiology of the ghrelin system, inadequate treatments could bring to contrasting or unsatisfactory results.

\section{Therapeutic Applications of Ghrelin}

The orexigenic and anti-inflammatory activities of ghrelin led to the hypothesis that exogenously administration of ghrelin could represent a therapeutic intervention for cachexia and inflammation and indeed several pilot studies on animal models and patients have demonstrated the beneficial effect of ghrelin on several pathological states (Fig. 1). Many others are registered on clinicalTrials.gov and are ongoing. The anti-inflammatory activity of ghrelin was demonstrated in vivo in several animal disease models, including colitis (Gonzalez-Rey et al. 2006), sepsis and sepsis-related organ dysfunctions (Chang et al. 2003a, 2003b; Chorny et al. 2008; Jacob et al. 2010; Peng et al. 2012; Wang et al. 2009; Wu et al. 2005, 2007a, b, c, 2009, 2012), and encephalomyelitis (Souza-Moreira et al. 2013; Theil et al. 2009).

In addition, in both human patients and experimental animal models, ghrelin administration ameliorates the cachectic state associated with several pathological conditions - such as chronic heart failure (Nagaya et al. 2004), chronic kidney disease (DeBoer et al. 2008), cancer (Argilés and Stemmler 2013; Neary et al. 2004; DeBoer et al. 2007), burn injuries (Balasubramaniam et al. 2006), and COPD (Nagaya et al. 2005)-likely through activity on both the immune system and the skeletal muscle (Reano et al. 2014).

Although ghrelin may undeniably inhibit cachexia through the GHS-R1a-mediated anti-inflammatory and orexigenic activities, some evidences prove that both acylated and unacylated ghrelin have a direct anti-atrophic activity in skeletal muscles: unacylated ghrelin, which does 


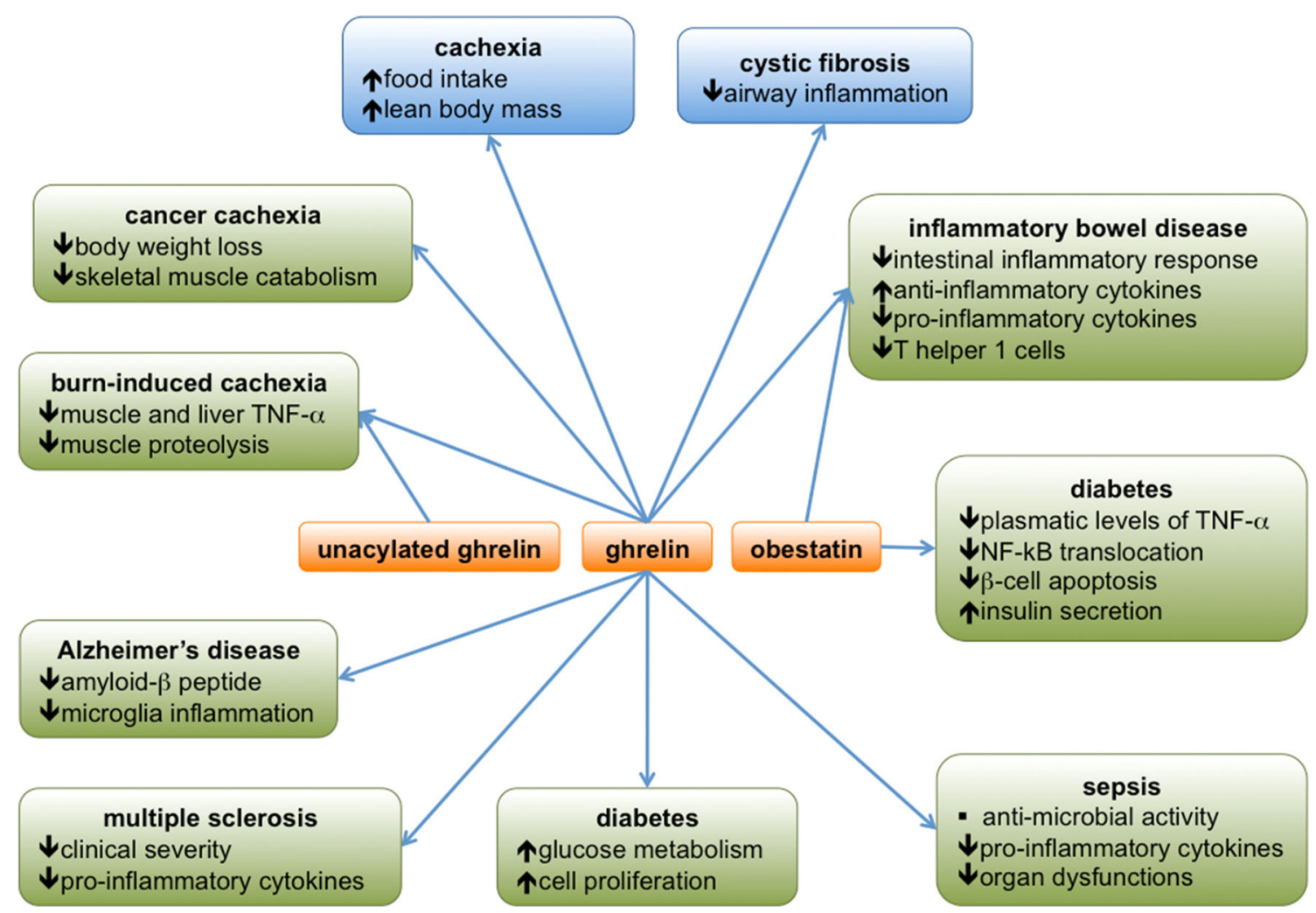

Fig. 1 Main effects of ghrelin, unacylated ghrelin, and obestatin treatments on animal models of inflammatory pathologies (in green) and human diseases (in blue). See text for details

not bind GHS-R1a and does not activate the GH/IGF-1 axis, reduces burn-induced skeletal muscle proteolysis and TNF- $\alpha$ up-regulation in rats (Sheriff et al. 2012), counteracts muscle atrophy induced by either fasting or denervation, and, as a final point, both acylated and unacylated peptides impairs fasting-induced atrophy in Ghsr null mice (Porporato et al. 2013).

\section{Conclusions}

Ghrelin has a potent anti-inflammatory activity, and its ability to inhibit pro-inflammatory cytokines expression and release has been demonstrated by a huge number of studies, both in vitro and in vivo. The anti-inflammatory effects of the other products of the ghrelin gene-unacylated ghrelin and obestatin-have not been thoroughly investigated yet, although some studies attest their antiinflammatory action on different tissues.

In both humans and animal models, ghrelin circulating concentrations increase in several inflammatory and autoimmune diseases that may be frequently associated with cachexia and anorexia. This increase may represent a compensatory mechanism of the organism in the attempt at re-establishing an optimal energetic balance, stimulating food intake, inhibiting muscle wasting, and fighting inflammation. Alternatively, as some experimental evidences in mice models of cachexia suggest, the increase in ghrelin levels in cachectic states may represent a hallmark of the establishment of a ghrelin resistance. On the other hand, in some diseases, it remains difficult to discern the primary cause for altered circulating ghrelin levels. It cannot be ruled out that in conditions of altered gut health like Crohn's disease or atrophic gastritis, changed ghrelin levels are a feedback response to alterations in nutrient absorption, gastro-intestinal function, and caloric intake.

Several clinical trials were designed to treat cachectic patients with the administration of ghrelin, ghrelin analogs, and GHS-R1a agonists in order to stimulate food intake, increase body mass weight and functionality, reduce the inflammation, thus ameliorating the overall physical condition. The therapeutic potential of unacylated ghrelin and obestatin administration, on the contrary, is so far totally unexplored, although the available data on animal studies are encouraging and suggest that also these two peptides could represent a valuable strategy to treat inflammatory and autoimmune diseases. In addition, the use of unacylated ghrelin or obestatin could also represent an alternative to ghrelin treatment in conditions in which the activation of the GH-IGF-1 axis or the potential diabetogenic side effect 
of ghrelin could be more detrimental than beneficial for the patient.

Acknowledgments The authors thank Omar Sabry for the critical reading of the manuscript and for the help with the figure.

\section{References}

Agnew AJ, Robinson E, McVicar CM et al (2012) The gastrointestinal peptide obestatin induces vascular relaxation via specific activation of endothelium-dependent NO signalling. Br J Pharmacol 166:327-338

Alexandridis E, Zisimopoulos A, Liratzopoulos N et al (2009) Obestatin/ghrelin ratio: a new activity index in inflammatory bowel diseases. Inflamm Bowel Dis 15:1557-1561

Alloatti G, Arnoletti E, Bassino E et al (2010) Obestatin affords cardioprotection to the ischemic-reperfused isolated rat heart and inhibits apoptosis in cultures of similarly stressed cardiomyocytes. Am J Physiol Heart Circ Physiol 299:H470-H481

Alonso N, Granada ML, Salinas I et al (2007) Plasma ghrelin concentrations in type 1 diabetic patients with autoimmune atrophic gastritis. Eur J Endocrinol 157:763-769

Altinova AE, Toruner F, Karakoc A et al (2006) Serum ghrelin levels in patients with Hashimoto's thyroiditis. Thyroid 16:1259-1264

Anderwald-Stadler M, Krebs M, Promintzer M et al (2007) Plasma obestatin is lower at fasting and not suppressed by insulin in insulin-resistant humans. Am J Physiol Endocrinol Metab 293:E1393-E1398

Aragno M, Mastrocola R, Ghé C et al (2012) Obestatin induced recovery of myocardial dysfunction in type 1 diabetic rats: underlying mechanisms. Cardiovasc Diabetol 11:129

Argilés JM, Stemmler B (2013) The potential of ghrelin in the treatment of cancer cachexia. Expert Opin Biol Ther 13:67-76

Ariyasu H, Takaya K, Tagami T et al (2001) Stomach is a major source of circulating ghrelin, and feeding state determines plasma ghrelin-like immunoreactivity levels in humans. J Clin Endocrinol Metab 86:4753-4758

Asakawa A, Inui A, Fujimiya M et al (2005) Stomach regulates energy balance via acylated ghrelin and desacyl ghrelin. Gut 54:18-24

Ashraf A, Mick G, Meleth S et al (2007) Insulin treatment reduces pre-prandial plasma ghrelin concentrations in children with type 1 diabetes. Med Sci Monit 13:CR533-CR537

Ates Y, Degertekin B, Erdil A et al (2008) Serum ghrelin levels in inflammatory bowel disease with relation to disease activity and nutritional status. Dig Dis Sci 53:2215-2221

Azevedo-Pinto S, Pereira-Silva P, Rocha-Sousa A (2013) Ghrelin in ocular pathophysiology: from the anterior to the posterior segment. Peptides 47:12-19

Baatar D, Patel K, Taub DD (2011) The effects of ghrelin on inflammation and the immune system. Mol Cell Endocrinol 340:44-58

Balasubramaniam A, Wood S, Joshi R et al (2006) Ghrelin stimulates food intake and growth hormone release in rats with thermal injury: synthesis of ghrelin. Peptides 27:1624-1631

Baldanzi G, Filigheddu N, Cutrupi S et al (2002) Ghrelin and des-acyl ghrelin inhibit cell death in cardiomyocytes and endothelial cells through ERK1/2 and PI 3-kinase/AKT. J Cell Biol 159:1029-1037

Bando M, Iwakura H, Ariyasu H et al (2013) Overexpression of intraislet ghrelin enhances $\beta$-cell proliferation after streptozotocin-induced $\beta$-cell injury in mice. Am J Physiol Endocrinol Metab 305:E140-E148
Bansal V, Ryu SY, Lopez N et al (2012) Vagal stimulation modulates inflammation through a ghrelin mediated mechanism in traumatic brain injury. Inflammation 35:214-220

Baragli A, Grande C, Gesmundo I et al (2013) Obestatin enhances in vitro generation of pancreatic islets through regulation of developmental pathways. PLoS ONE 8:e64374

Barazzoni R, Semolic A, Cattin MR et al (2014) Acylated ghrelin limits fat accumulation and improves redox state and inflammation markers in the liver of high-fat-fed rats. Obesity 22:170-177

Bassil AK, Häglund Y, Brown J et al (2007) Little or no ability of obestatin to interact with ghrelin or modify motility in the rat gastrointestinal tract. Br J Pharmacol 150:58-64

Beck B, Pourié G (2013) Ghrelin, neuropeptide Y, and other feedingregulatory peptides active in the hippocampus: role in learning and memory. Nutr Rev 71:541-561

Bednarek MA, Feighner SD, Pong SS et al (2000) Structure-function studies on the new growth hormone-releasing peptide, ghrelin: minimal sequence of ghrelin necessary for activation of growth hormone secretagogue receptor 1a. J Med Chem 43:4370-4376

Benso A, Prodam F, Lucatello B et al (2007) d-Lys-GHRP-6 does not modify the endocrine response to acylated ghrelin or hexarelin in humans. Neuropeptides 41:45-49

Benso A, St-Pierre DH, Prodam F et al (2012) Metabolic effects of overnight continuous infusion of unacylated ghrelin in humans. Eur J Endocrinol 166:911-916

Berilgen MS, Bulut S, Ustundag B et al (2005) Patients with multiple sclerosis have higher levels of serum ghrelin. Neuro Endocrinol Lett 26:819-822

Bideci A, Camurdan MO, Cinaz P et al (2005) Ghrelin, IGF-I and IGFBP-3 levels in children with type 1 diabetes mellitus. J Pediatr Endocrinol Metab 18:1433-1499

Bossowski A, Czarnocka B, Harasymczuk J et al (2013) Identification of GPR39 receptor and ghrelin receptor in thyroid tissues in paediatric patients with immune and non-immune thyroid diseases. Horm Res Paediatr 79:130-136

Broglio F, Gottero C, Prodam F et al (2004) Non-acylated ghrelin counteracts the metabolic but not the neuroendocrine response to acylated ghrelin in humans. J Clin Endocrinol Metab 89:3062-3065

Broglio F, Prodam F, Riganti F et al (2008) The continuous infusion of acylated ghrelin enhances growth hormone secretion and worsens glucose metabolism in humans. J Endocrinol Invest 31:788-794

Bulgarelli I, Tamiazzo L, Bresciani E et al (2009) Desacyl-ghrelin and synthetic GH-secretagogues modulate the production of inflammatory cytokines in mouse microglia cells stimulated by beta-amyloid fibrils. J Neurosci Res 87:2718-2727

Capristo E, Farnetti S, Mingrone G et al (2005) Reduced plasma ghrelin concentration in celiac disease after gluten-free diet treatment. Scand J Gastroenterol 40:430-436

Cassoni P, Papotti M, Ghè C et al (2001) Identification, characterization, and biological activity of specific receptors for natural (ghrelin) and synthetic growth hormone secretagogues and analogs in human breast carcinomas and cell lines. J Clin Endocrinol Metab 86:1738-1745

Cassoni P, Ghé C, Marrocco T et al (2004) Expression of ghrelin and biological activity of specific receptors for ghrelin and des-acyl ghrelin in human prostate neoplasms and related cell lines. Eur J Endocrinol 150:173-184

Celi F, Bini V, Papi F et al (2005) Circulating acylated and total ghrelin and galanin in children with insulin-treated type 1 diabetes: relationship to insulin therapy, metabolic control and pubertal development. Clin Endocrinol 63:139-145

Chang L, Du JB, Gao LR et al (2003a) Effect of ghrelin on septic shock in rats. Acta Pharmacol Sin 24:45-49 
Chang L, Zhao J, Yang J et al (2003b) Therapeutic effects of ghrelin on endotoxic shock in rats. Eur J Pharmacol 473:171-176

Chartrel N, Alvear-Perez R, Leprince J et al (2007) Comment on "Obestatin, a peptide encoded by the ghrelin gene, opposes ghrelin's effects on food intake". Science 315:766

Checchi S, Montanaro A, Pasqui L et al (2007) Serum ghrelin as a marker of atrophic body gastritis in patients with parietal cell antibodies. J Clin Endocrinol Metab 92:4346-4351

Chen CY, Tsai CY (2012) Ghrelin and motilin in the gastrointestinal system. Curr Pharm Des 18:4755-4765

Chen Y, Cao CP, Li CR et al (2010) Ghrelin modulates insulin sensitivity and tau phosphorylation in high glucose-induced hippocampal neurons. Biol Pharm Bull 33:1165-1169

Chen CY, Tsai CY, Lee PC et al (2013) Long-term etanercept therapy favors weight gain and ameliorates cachexia in rheumatoid arthritis patients: roles of gut hormones and leptin. Curr Pharm Des 19:1956-1964

Cheng B, Wan J, Wang Y et al (2010) Ghrelin inhibits foam cell formation via simultaneously down-regulating the expression of acyl-coenzyme A: cholesterol acyltransferase 1 and up-regulating adenosine triphosphate-binding cassette transporter A1. Cardiovasc Pathol 19:e159-e166

Cheyuo C, Wu R, Zhou M et al (2011) Ghrelin suppresses inflammation and neuronal nitric oxide synthase in focal cerebral ischemia via the vagus nerve. Shock 35:258-265

Chorny A, Anderson P, Gonzalez-Rey E et al (2008) Ghrelin protects against experimental sepsis by inhibiting high-mobility group box 1 release and by killing bacteria. J Immunol 180:8369-8377

Chung H, Seo S, Moon M et al (2008) Phosphatidylinositol-3-kinase/ Akt/glycogen synthase kinase-3 beta and ERK1/2 pathways mediate protective effects of acylated and unacylated ghrelin against oxygen-glucose deprivation-induced apoptosis in primary rat cortical neuronal cells. J Endocrinol 198:511-521

Cohen RI, Tsang D, Koenig S et al (2008) Plasma ghrelin and leptin in adult cystic fibrosis patients. J Cyst Fibros 7:398-402

Cohen RI, Chandra S, Koenig S et al (2010) Ghrelin receptor expression in lymphocytes isolated from adult cystic fibrosis patients. Respiration 79:141-146

Coskun ZM, Sacan O, Karatug A et al (2013) Regulation of oxidative stress and somatostatin, cholecystokinin, apelin gene expressions by ghrelin in stomach of newborn diabetic rats. Acta Histochem 115:740-747

Cui AD, Gai NN, Zhang XH et al (2012) Decreased serum obestatin consequent upon TRIB3 Q84R polymorphism exacerbates carotid atherosclerosis in subjects with metabolic syndrome. Diabetol Metab Syndr 4:52

Cummings DE (2006) Ghrelin and the short- and long-term regulation of appetite and body weight. Physiol Behav 89:71-84

Cummings DE, Clement K, Purnell JQ et al (2002) Elevated plasma ghrelin levels in Prader Willi syndrome. Nat Med 8:643-644

de Lecea L, Castaño JP (2006) Cortistatin: not just another somatostatin analog. Nat Clin Pract Endocrinol Metab 2:356-357

De Smet B, Thijs T, Moechars D et al (2009) Endogenous and exogenous ghrelin enhance the colonic and gastric manifestations of dextran sodium sulphate-induced colitis in mice. Neurogastroenterol Motil 21:59-70

DeBoer MD, Zhu XX, Levasseur P et al (2007) Ghrelin treatment causes increased food intake and retention of lean body mass in a rat model of cancer cachexia. Endocrinology 148:3004-3012

DeBoer MD, Zhu X, Levasseur PR et al (2008) Ghrelin treatment of chronic kidney disease: improvements in lean body mass and cytokine profile. Endocrinology 149:827-835

Delgado M, Ganea D (2008) Anti-inflammatory neuropeptides: a new class of endogenous immunoregulatory agents. Brain Behav Immun 22:1146-1151
Delhanty PJ, van der Eerden BC, van der Velde M et al (2006) Ghrelin and unacylated ghrelin stimulate human osteoblast growth via mitogen-activated protein kinase (MAPK)/phosphoinositide 3-kinase (PI3K) pathways in the absence of GHSR-1a. J Endocrinol 188:37-47

Delhanty PJ, van Koetsveld PM, Gauna C et al (2007) Ghrelin and its unacylated isoform stimulate the growth of adrenocortical tumor cells via an anti-apoptotic pathway. Am J Physiol Endocrinol Metab 293:E302-E309

Delhanty PJ, Huisman M, Baldeon-Rojas LY et al (2013) Des-acyl ghrelin analogs prevent high-fat-diet-induced dysregulation of glucose homeostasis. FASEB J 27:1690-1700

Demers A, McNicoll N, Febbraio M et al (2004) Identification of the growth hormone-releasing peptide binding site in CD36: a photoaffinity cross-linking study. Biochem J 382:417-424

Demers A, Caron V, Rodrigue-Way A et al (2009) A concerted kinase interplay identifies PPARgamma as a molecular target of ghrelin signaling in macrophages. PLoS ONE 4:e7728

Depoortere I, Thijs T, Peeters T (2006) The contractile effect of the ghrelin receptor antagonist, D-Lys3-GHRP-6, in rat fundic strips is mediated through 5-HT receptors. Eur J Pharmacol 537:160-165

Dhurandhar EJ, Allison DB, van Groen T et al (2013) Hunger in the absence of caloric restriction improves cognition and attenuates Alzheimer's disease pathology in a mouse model. PLoS ONE 8:e60437

Dixit VD, Schaffer EM, Pyle RS et al (2004) Ghrelin inhibits leptinand activation-induced proinflammatory cytokine expression by human monocytes and T cells. J Clin Invest 114:57-66

Doi A, Shono T, Nishi M et al (2006) IA-2beta, but not IA-2, is induced by ghrelin and inhibits glucose-stimulated insulin secretion. Proc Natl Acad Sci USA 103:885-890

Dong J, Peeters TL, De Smet B et al (2006) Role of endogenous ghrelin in the hyperphagia of mice with streptozotocin-induced diabetes. Endocrinology 147:2634-2642

Egido EM, Hernández R, Marco J et al (2009) Effect of obestatin on insulin, glucagon and somatostatin secretion in the perfused rat pancreas. Regul Pept 152:61-66

El Eter E, Al Tuwaijiri A, Hagar $\mathrm{H}$ et al (2007) In vivo and in vitro antioxidant activity of ghrelin: attenuation of gastric ischemic injury in the rat. J Gastroenterol Hepatol 22:1791-1799

Erriquez J, Bernascone S, Ciarletta M et al (2009) Calcium signals activated by ghrelin and D-Lys(3)-GHRP-6 ghrelin antagonist in developing dorsal root ganglion glial cells. Cell Calcium 46:197-208

Favaro E, Granata R, Miceli I et al (2012) The ghrelin gene products and exendin-4 promote survival of human pancreatic islet endothelial cells in hyperglycaemic conditions, through phosphoinositide 3-kinase/Akt, extracellular signal-related kinase (ERK) $1 / 2$ and cAMP/protein kinase A (PKA) signalling pathways. Diabetologia 55:1058-1070

Filigheddu N, Gnocchi VF, Coscia M et al (2007) Ghrelin and desacyl ghrelin promote differentiation and fusion of $\mathrm{C} 2 \mathrm{C} 12$ skeletal muscle cells. Mol Biol Cell 18:986-994

Gahete MD, Rubio A, Córdoba-Chacón J et al (2010) Expression of the ghrelin and neurotensin systems is altered in the temporal lobe of Alzheimer's disease patients. J Alzheimers Dis 22:819-828

Gao M, Yang J, Liu G et al (2012) Ghrelin promotes the differentiation of human embryonic stem cells in infarcted cardiac microenvironment. Peptides 34:373-379

Gao M, Yang J, Wei R et al (2013) Ghrelin induces cardiac lineage differentiation of human embryonic stem cells through ERK1/2 pathway. Int J Cardiol 167:2724-2733

Garcia JM, Garcia-Touza M, Hijazi RA et al (2005) Active ghrelin levels and active to total ghrelin ratio in cancer-induced cachexia. J Clin Endocrinol Metab 90:2920-2926 
García-García F, Juárez-Aguilar E, Santiago-García J et al (2014) Ghrelin and its interactions with growth hormone, leptin and orexins: implications for the sleep-wake cycle and metabolism. Sleep Med Rev 18:89-97

Gauna C, Delhanty PJ, Hofland LJ et al (2005) Ghrelin stimulates, whereas des-octanoyl ghrelin inhibits, glucose output by primary hepatocytes. J Clin Endocrinol Metab 90:1055-1060

Gauna C, van de Zande B, van Kerkwijk A et al (2007) Unacylated ghrelin is not a functional antagonist but a full agonist of the type 1a growth hormone secretagogue receptor (GHS-R). Mol Cell Endocrinol 274:30-34

Gelling RW, Overduin J, Morrison CD et al (2004) Effect of uncontrolled diabetes on plasma ghrelin concentrations and ghrelin-induced feeding. Endocrinology 145:4575-4582

Genoni G, Prodam F, Marolda A et al (2014) Obesity and infection: two sides of one coin. Eur J Pediatr 173:25-32

Giovambattista A, Gaillard RC, Spinedi E (2008) Ghrelin generelated peptides modulate rat white adiposity. Vitam Horm 77:171-205

Gnanapavan S, Kola B, Bustin SA et al (2002) The tissue distribution of the mRNA of ghrelin and subtypes of its receptor, GHS-R, in humans. J Clin Endocrinol Metab 87:2988-2991

Goebel-Stengel M, Hofmann T, Elbelt U et al (2013) The ghrelin activating enzyme ghrelin- $O$-acyltransferase (GOAT) is present in human plasma and expressed dependent on body mass index. Peptides 43:13-19

Gonzalez-Gay MA, Garcia-Unzueta MT, Berja A et al (2008) Antitumour necrosis factor alpha therapy modulates ghrelin in patients with severe rheumatoid arthritis. Ann Rheum Dis 67:1644-1646

Gonzalez-Rey E, Chorny A, Delgado M (2006) Therapeutic action of ghrelin in a mouse model of colitis. Gastroenterology 130:1707-1720

Granata R, Settanni F, Biancone L et al (2007) Acylated and unacylated ghrelin promote proliferation and inhibit apoptosis of pancreatic beta-cells and human islets: involvement of $3^{\prime}, 5^{\prime}$ cyclic adenosine monophosphate/protein kinase A, extracellular signal-regulated kinase 1/2, and phosphatidyl inositol 3-kinase/ Akt signaling. Endocrinology 148:512-529

Granata R, Settanni F, Gallo D et al (2008) Obestatin promotes survival of pancreatic beta-cells and human islets and induces expression of genes involved in the regulation of beta-cell mass and function. Diabetes 57:967-979

Granata R, Volante M, Settanni F et al (2010) Unacylated ghrelin and obestatin increase islet cell mass and prevent diabetes in streptozotocin-treated newborn rats. J Mol Endocrinol 45:9-17

Granata R, Gallo D, Luque RM et al (2012) Obestatin regulates adipocyte function and protects against diet-induced insulin resistance and inflammation. FASEB J 26:3393-3411

Gül FC, Turgut B, Dağlı F et al (2013) The comparison of the impact of ghrelin and tacrolimus on vitreous cytokine levels in an experimental uveitis model. Graefes Arch Clin Exp Ophthalmol 251:1235-1241

Guo ZF, Zheng X, Qin YW et al (2007) Circulating preprandial ghrelin to obestatin ratio is increased in human obesity. J Clin Endocrinol Metab 92:1875-1880

Guo ZF, Ren AJ, Zheng X et al (2008) Different responses of circulating ghrelin, obestatin levels to fasting, re-feeding and different food compositions, and their local expressions in rats. Peptides 29:1247-1254

Gurriarán-Rodríguez U, Al-Massadi O, Roca-Rivada A et al (2011) Obestatin as a regulator of adipocyte metabolism and adipogenesis. J Cell Mol Med 15:1927-1940

Gurriarán-Rodríguez U, Santos-Zas I, Al-Massadi O et al (2012) The obestatin/GPR39 system is up-regulated by muscle injury and functions as an autocrine regenerative system. J Biol Chem 287:38379-38389
Habegger KM, Grant E, Pfluger PT et al (2011) Ghrelin receptor deficiency does not affect diet-induced atherosclerosis in lowdensity lipoprotein receptor-null mice. Front Endocrinol 2:67

Hattori N, Saito T, Yagyu T et al (2001) GH, GH receptor, GH secretagogue receptor, and ghrelin expression in human $\mathrm{T}$ cells, B cells, andneutrophils. J Clin Endocrinol Metab 86:4284-4291

Heppner KM, Piechowski CL, Müller A et al (2014) Both acyl and des-acyl ghrelin regulate adiposity and glucose metabolism via central nervous system ghrelin receptors. Diabetes 63:122-131

Holdstock C, Ludvigsson J, Karlsson FA (2004) Abnormal ghrelin secretion in new onset childhood Type 1 diabetes. Diabetologia $47: 150-151$

Hosomi S, Oshitani N, Kamata N et al (2008) Phenotypical and functional study of ghrelin and its receptor in the pathogenesis of Crohn's disease. Inflamm Bowel Dis 14:1205-1213

Hou Y, An J, Hu XR et al (2009) Ghrelin inhibits interleukin-8 production induced by hydrogen peroxide in A549 cells via NFkappaB pathway. Int Immunopharmacol 9:120-126

Huml M, Kobr J, Siala K et al (2011) Gut peptide hormones and pediatric type 1 diabetes mellitus. Physiol Res 60:647-658

Hwang S, Moon M, Kim S et al (2009) Neuroprotective effect of ghrelin is associated with decreased expression of prostate apoptosis response-4. Endocr J 56:609-617

Inhoff T, Mönnikes H, Noetzel S et al (2008) Desacyl ghrelin inhibits the orexigenic effect of peripherally injected ghrelin in rats. Peptides 29:2159-2168

Irako T, Akamizu T, Hosoda $\mathrm{H}$ et al (2006) Ghrelin prevents development of diabetes at adult age in streptozotocin-treated newborn rats. Diabetologia 49:1264-1273

Itoh T, Nagaya N, Yoshikawa M et al (2004) Elevated plasma ghrelin level in underweight patients with chronic obstructive pulmonary disease. Am J Respir Crit Care Med 170:879-882

Jacob A, Rajan D, Pathickal B et al (2010) The inhibitory effect of ghrelin on sepsis-induced inflammation is mediated by the MAPK phosphatase-1. Int J Mol Med 25:159-164

Jarocka-Cyrta E, Kasacka I, Kaczmarski M (2010) The ghrelinpositive cells number is increased in duodenum in children with celiac disease. J Endocrinol Invest 33:165-170

Jeffery PL, Herington AC, Chopin LK (2002) Expression and action of the growth hormone releasing peptide ghrelin and its receptor in prostate cancer cell lines. J Endocrinol 172:R7-R11

Karagiozoglou-Lampoudi T, Trachana M, Agakidis C et al (2011) Ghrelin levels in patients with juvenile idiopathic arthritis: relation to anti-tumor necrosis factor treatment and disease activity. Metabolism 60:1359-1362

Karaoglu A, Aydin S, Dagli AF et al (2009) Expression of obestatin and ghrelin in papillary thyroid carcinoma. Mol Cell Biochem 323:113-118

Karmiris K, Koutroubakis IE, Xidakis C et al (2006) Circulating levels of leptin, adiponectin, resistin, and ghrelin in inflammatory bowel disease. Inflamm Bowel Dis 12:100-105

Katugampola SD, Pallikaros Z, Davenport AP (2001) [125I-His(9)]ghrelin, a novel radioligand for localizing GHS orphan receptors in human and rat tissue: up-regulation of receptors with athersclerosis. Br J Pharmacol 134:143-149

Kellokoski E, Kunnari A, Jokela M et al (2009) Ghrelin and obestatin modulate early atherogenic processes on cells: enhancement of monocyte adhesion and oxidized low-density lipoprotein binding. Metabolism 58:1572-1580

Kerem M, Ferahkose Z, Yilmaz UT et al (2008) Adipokines and ghrelin in gastric cancer cachexia. World J Gastroenterol 14:3633-3641

Koca SS, Ozgen M, Aydin S et al (2008) Ghrelin and obestatin levels in rheumatoid arthritis. Inflammation 31:329-335

Kodama T, Ashitani J, Matsumoto N et al (2008) Ghrelin administration suppressed airway inflammation by decreasing neutrophil 
accumulation in lungs and increased body weight. Pulm Pharmacol Ther 21:774-779

Kojima M, Hosoda H, Date Y et al (1999) Ghrelin is a growthhormone-releasing acylated peptide from stomach. Nature 402:656-660

Konturek PC, Brzozowski T, Walter B et al (2006) Ghrelin-induced gastroprotection against ischemia-reperfusion injury involves an activation of sensory afferent nerves and hyperemia mediated by nitric oxide. Eur J Pharmacol 536:171-181

Kotani K, Sakane N, Saiga K et al (2006) Serum ghrelin and carotid atherosclerosis in older Japanese people with metabolic syndrome. Arch Med Res 37:903-906

Kümpers P, Horn R, Brabant G et al (2008) Serum leptin and ghrelin correlate with disease activity in ANCA-associated vasculitis. Rheumatology 47:484-487

Kwan RO, Cureton E, Dozier K et al (2010) Ghrelin decreases microvascular leak during inflammation. J Trauma 68:1186-1191

Lacquaniti A, Donato V, Chirico V et al (2011) Obestatin: an interesting but controversial gut hormone. Ann Nutr Metab 59:193-199

Lanzini A, Magni P, Petroni ML et al (2006) Circulating ghrelin level is increased in coeliac disease as in functional dyspepsia and reverts to normal during gluten-free diet. Aliment Pharmacol Ther 23:907-913

Lauwers E, Landuyt B, Arckens L et al (2006) Obestatin does not activate orphan $\mathrm{G}$ protein-coupled receptor GPR39. Biochem Biophys Res Commun 351:21-25

Lee S, Kim Y, Li E et al (2012) Ghrelin protects spinal cord motoneurons against chronic glutamate excitotoxicity by inhibiting microglial activation. Korean J Physiol Pharmacol 16:43-48

Li WG, Gavrila D, Liu X et al (2004) Ghrelin inhibits proinflammatory responses and nuclear factor-kappaB activation in human endothelial cells. Circulation 109:2221-2226

Liu L, Xu H, Jiang $\mathrm{H}$ et al (2010) Ghrelin prevents 1-methyl-4phenylpyridinium ion-induced cytotoxicity through antioxidation and NF-kappaB modulation in MES23.5 cells. Exp Neurol 222:25-29

Magiera M, Kopec-Medrek M, Widuchowska M et al (2013) Serum ghrelin in female patients with rheumatoid arthritis during treatment with infliximab. Rheumatol Int 33:1611-1613

Martins I, Gomes S, Costa RO et al (2013) Leptin and ghrelin prevent hippocampal dysfunction induced by $\mathrm{A} \beta$ oligomers. Neuroscience 241:41-51

Martos-Moreno GA, Barrios V, Soriano-Guillén L et al (2006) Relationship between adiponectin levels, acylated ghrelin levels, and short-term body mass index changes in children with diabetes mellitus type 1 at diagnosis and after insulin therapy. Eur J Endocrinol 155:757-761

Maruna P, Gürlich R, Frasko R et al (2005) Ghrelin and leptin elevation in postoperative intra-abdominal sepsis. Eur Surg Res 37:354-359

Matsumoto M, Hosoda H, Kitajima Y et al (2001) Structure-activity relationship of ghrelin: pharmacological study of ghrelin peptides. Biochem Biophys Res Commun 287:142-146

Miegueu P, St Pierre D, Broglio F et al (2011) Effect of desacyl ghrelin, obestatin and related peptides on triglyceride storage, metabolism and GHSR signaling in 3T3-L1 adipocytes. J Cell Biochem 112:704-714

Monajemzadeh M, Mokhtari S, Motamed F et al (2013) Plasma ghrelin levels in children with cystic fibrosis and healthy children. Arch Med Sci 9:93-97

Moon M, Kim HG, Hwang L et al (2009) Neuroprotective effect of ghrelin in the 1-methyl-4-phenyl-1,2,3,6-tetrahydropyridine mouse model of Parkinson's disease by blocking microglial activation. Neurotox Res 15:332-347
Moon M, Choi JG, Nam DW et al (2011) Ghrelin ameliorates cognitive dysfunction and neurodegeneration in intrahippocampal amyloid- $\beta 1-42$ oligomer-injected mice. J Alzheimers Dis 23:147-159

Morillo-Bernal J, Fernández-Santos JM, De Miguel M et al (2011) Ghrelin potentiates TSH-induced expression of the thyroid tissue-specific genes thyroglobulin, thyroperoxidase and sodium-iodine symporter, in rat $\mathrm{PC}-\mathrm{Cl} 3$ Cells. Peptides 32:2333-2339

Muccioli G, Pons N, Ghè C et al (2004) Ghrelin and des-acyl ghrelin both inhibit isoproterenol-induced lipolysis in rat adipocytes via a non-type 1a growth hormone secretagogue receptor. Eur J Pharmacol 498:27-35

Murdolo G, Lucidi P, Di Loreto C et al (2003) Insulin is required for prandial ghrelin suppression in humans. Diabetes 52:2923-2927

Nagaya N, Uematsu M, Kojima M et al (2001) Elevated circulating level of ghrelin in cachexia associated with chronic heart failure: relationships between ghrelin and anabolic/catabolic factors. Circulation 104:2034-2038

Nagaya N, Moriya J, Yasumura Y et al (2004) Effects of ghrelin administration on left ventricular function, exercise capacity, and muscle wasting in patients with chronic heart failure. Circulation 110:3674-3679

Nagaya N, Itoh T, Murakami S et al (2005) Treatment of cachexia with ghrelin in patients with COPD. Chest 128:1187-1193

Nakahara T, Harada T, Yasuhara D et al (2008) Plasma obestatin concentrations are negatively correlated with body mass index, insulin resistance index, and plasma leptin concentrations in obesity and anorexia nervosa. Biol Psychiatry 64:252-255

Neary NM, Small CJ, Wren AM et al (2004) Ghrelin increases energy intake in cancer patients with impaired appetite: acute, randomized, placebo-controlled trial. J Clin Endocrinol Metab 89:2832-2836

Pamukcu O, Kumral ZN, Ercan F et al (2013) Anti-inflammatory effect of obestatin and ghrelin in dextran sulfate sodium-induced colitis in rats. J Pediatr Gastroenterol Nutr 57:211-218

Patel K, Dixit VD, Lee JH et al (2012a) Identification of ghrelin receptor blocker, D-[Lys3] GHRP-6 as a CXCR4 receptor antagonist. Int J Biol Sci 8:108-117

Patel K, Dixit VD, Lee JH et al (2012b) The GHS-R blocker D-[Lys3] GHRP-6 serves as CCR5 chemokine receptor antagonist. Int J Med Sci 9:51-58

Peng Z, Zhu Y, Zhang Y et al (2012) Effects of ghrelin on pulmonary NOD2 mRNA expression and NF- $\kappa \mathrm{B}$ activation when protects against acute lung injury in rats challenged with cecal ligation and puncture. Int Immunopharmacol 13:440-445

Peracchi M, Conte D, Terrani C et al (2003) Circulating ghrelin levels in celiac patients. Am J Gastroenterol 98:2474-2478

Porporato PE, Filigheddu N, Reano S et al (2013) Acylated and unacylated ghrelin impair skeletal muscle atrophy in mice. J Clin Invest 123:611-622

Portelli J, Michotte Y, Smolders I (2012) Ghrelin: an emerging new anticonvulsant neuropeptide. Epilepsia 53:585-595

Pöykkö SM, Kellokoski E, Ukkola O et al (2006) Plasma ghrelin concentrations are positively associated with carotid artery atherosclerosis in males. J Intern Med 260:43-52

Prodam F, Bellone S, Corneli G et al (2008) Ghrelin: a molecular target for weight regulation, glucose and lipid metabolism. Recents Patents Endocr Metab Immune Drug Discov 2:172-177

Prodam F, Trovato L, Demarchi I et al (2011) Unacylated, acylated ghrelin and obestatin levels are differently inhibited by oral glucose load in pediatric obesity: association with insulin sensitivity and metabolic alterations. Eur J Clin Nutr Metab 6:e109-e115

Prodam F, Cadario F, Bellone S et al (2014) Obestatin levels are associated with C-peptide and anti-insulin antibodies at the onset 
whereas unacylated and acylated ghrelin levels are not predictive of long-term metabolic control in children with type 1 diabetes. J Clin Endocrinol Metab jc20133294

Proto C, Romualdi D, Cento RM et al (2006) Plasma levels of neuropeptides in Alzheimer's disease. Gynecol Endocrinol 22:213-218

Pruszynska-Oszmalek E, Szczepankiewicz D, Hertig I et al (2013) Obestatin inhibits lipogenesis and glucose uptake in isolated primary rat adipocytes. J Biol Regul Homeost Agents 27:23-33

Raimondo S, Ronchi G, Geuna S et al (2013) Ghrelin: a novel neuromuscular recovery promoting factor? Int Rev Neurobiol 108:207-221

Reano S, Graziani A, Filigheddu N (2014) Acylated and unacylated ghrelin administration to blunt muscle wasting. Curr Opin Clin Nutr Metab Care (Epub ahead of print)

Reinehr T, de Sousa G, Roth CL (2008) Obestatin and ghrelin levels in obese children and adolescents before and after reduction of overweight. Clin Endocrinol 68:304-310

Rey LK, Wieczorek S, Akkad DA et al (2011) Polymorphisms in genes encoding leptin, ghrelin and their receptors in German multiple sclerosis patients. Mol Cell Probes 25:255-259

Rezaeian F, Wettstein R, Scheuer C et al (2012) Ghrelin protects musculocutaneous tissue from ischemic necrosis by improving microvascular perfusion. Am J Physiol Heart Circ Physiol 302:H603-H610

Rocco A, Sarnelli G, Compare D et al (2008) Tissue ghrelin level and gastric emptying rate in adult patients with celiac disease. Neurogastroenterol Motil 20:884-890

Rodríguez A, Gómez-Ambrosi J, Catalán V et al (2012) The ghrelin $O$-acyltransferase-ghrelin system reduces TNF- $\alpha$-induced apoptosis and autophagy in human visceral adipocytes. Diabetologia 55:3038-3050

Samson WK, White MM, Price C et al (2007) Obestatin acts in brain to inhibit thirst. Am J Physiol Regul Integr Comp Physiol 292:R637-R643

Samson WK, Yosten GL, Chang JK et al (2008) Obestatin inhibits vasopressin secretion: evidence for a physiological action in the control of fluid homeostasis. J Endocrinol 196:559-564

Sawicka B, Bossowski A, Szalecki M et al (2010) Relationship between metabolic parameters and thyroid hormones and the level of gastric peptides in children with autoimmune thyroid diseases. J Pediatr Endocrinol Metab 23:345-354

Schellekens H, McNamara O, Dinan TG et al (2013) Semagacestat, a $\gamma$-secretase inhibitor, activates the growth hormone secretagogue (GHSR-1a) receptor. J Pharm Pharmacol 65:528-538

Selimoglu MA, Altinkaynak S, Ertekin V et al (2006) Serum ghrelin levels in children with celiac disease. J Clin Gastroenterol 40:191-194

Sheriff S, Kadeer N, Joshi R et al (2012) Des-acyl ghrelin exhibits pro-anabolic and anti-catabolic effects on $\mathrm{C} 2 \mathrm{C} 12$ myotubes exposed to cytokines and reduces burn-induced muscle proteolysis in rats. Mol Cell Endocrinol 351:286-295

Shimizu Y, Nagaya N, Isobe $\mathrm{T}$ et al (2003) Increased plasma ghrelin level in lung cancer cachexia. Clin Cancer Res 9:774-778

Skilton MR, Nakhla S, Sieveking DP et al (2005) Pathophysiological levels of the obesity related peptides resistin and ghrelin increase adhesion molecule expression on human vascular endothelial cells. Clin Exp Pharmacol Physiol 32:839-844

Skurlova M, Stofkova A, Kiss A et al (2010) Transient anorexia, hyper-nociception and cognitive impairment in early adjuvant arthritis in rats. Endocr Regul 44:165-173

Slomiany BL, Slomiany A (2013) Involvement of p38 MAPKdependent activator protein (AP-1) activation in modulation of gastric mucosal inflammatory responses to Helicobacter pylori by ghrelin. Inflammopharmacology 21:67-78
Soriano-Guillén L, Barrios V, Lechuga-Sancho A et al (2004) Response of circulating ghrelin levels to insulin therapy in children with newly diagnosed type 1 diabetes mellitus. Pediatr Res 55:830-835

Souza-Moreira L, Delgado-Maroto V, Morell M et al (2013) Therapeutic effect of ghrelin in experimental autoimmune encephalomyelitis by inhibiting antigen-specific Th1/Th17 responses and inducing regulatory $\mathrm{T}$ cells. Brain Behav Immun 30:54-60

Stofkova A, Haluzik M, Zelezna B et al (2009) Enhanced expressions of mRNA for neuropeptide $\mathrm{Y}$ and interleukin 1 beta in hypothalamic arcuate nuclei during adjuvant arthritisinduced anorexia in Lewis rats. NeuroImmunoModulation 16:377-384

Sung EZ, Da Silva NF, Goodyear S et al (2009) Increased plasma ghrelin following infliximab in Crohn's disease. Aliment Pharmacol Ther 29:83-89

Sung EZ, Da Silva NF, Goodyear SJ et al (2011) Ghrelin promotes nuclear factor kappa-B activation in a human B-lymphocyte cell line. Mol Biol Rep 38:4833-4838

Takagi K, Legrand R, Asakawa A et al (2013) Anti-ghrelin immunoglobulins modulate ghrelin stability and its orexigenic effect in obese mice and humans. Nat Commun 4:2685

Taub DD (2008) Novel connections between the neuroendocrine and immune systems: the ghrelin immunoregulatory network. Vitam Horm 77:325-346

Terashi M, Asakawa A, Harada T et al (2011) Ghrelin reactive autoantibodies in restrictive anorexia nervosa. Nutrition 27:407-413

Theil MM, Miyake S, Mizuno M et al (2009) Suppression of experimental autoimmune encephalomyelitis by ghrelin. J Immunol 183:2859-2866

Theodoropoulou A, Metallinos IC, Psyrogiannis A et al (2012) Ghrelin and leptin secretion in patients with moderate Alzheimer's disease. J Nutr Health Aging 16:472-477

Togliatto G, Trombetta A, Dentelli P et al (2010) Unacylated ghrelin rescues endothelial progenitor cell function in individuals with type 2 diabetes. Diabetes 59:1016-1025

Toshinai K, Yamaguchi H, Sun Y et al (2006) Des-acyl ghrelin induces food intake by a mechanism independent of the growth hormone secretagogue receptor. Endocrinology 147:2306-2314

Toussirot E, Mourot L, Dehecq B et al (2013) TNF $\alpha$ blockade for inflammatory rheumatic diseases is associated with a significant gain in android fat mass and has varying effects on adipokines: a 2-year prospective study. Eur J Nutr. doi:10.1007/s00394-013$0599-2$

Tschöp M, Smiley DL, Heiman ML (2000) Ghrelin induces adiposity in rodents. Nature 407:908-913

Turgut B, Gül FC, Dağli F et al (2013) Impact of ghrelin on vitreous cytokine levels in an experimental uveitis model. Drug Des Devel Ther 7:19-24

Turk N, Dağistanli FK, Sacan O et al (2012) Obestatin and insulin in pancreas of newborn diabetic rats treated with exogenous ghrelin. Acta Histochem 114:349-357

Unger MM, Oertel WH, Tackenberg B (2013) Cerebrospinal fluid concentrations of ghrelin in patients with multiple sclerosis. Neuro Endocrinol Lett 34:14-17

Utrilla JC, Morillo-Bernal J, Gordillo-Martínez F et al (2013) Expression of hypothalamic regulatory peptides in thyroid $\mathrm{C}$ cells of different mammals. Gen Comp Endocrinol 187:6-14

van der Lely AJ, Tschop M, Heiman ML et al (2004) Biological, physiological, pathophysiological, and pharmacological aspects of ghrelin. Endocr Rev 25:426-457

van Hagen PM, Dalm VA, Staal F et al (2008) The role of cortistatin in the human immune system. Mol Cell Endocrinol 286:141-147 
Vicennati V, Genghini S, De Iasio R et al (2007) Circulating obestatin levels and the ghrelin/obestatin ratio in obese women. Eur J Endocrinol 157:295-301

Vila G, Maier C, Riedl M et al (2007) Bacterial endotoxin induces biphasic changes in plasma ghrelin in healthy humans. J Clin Endocrinol Metab 92:3930-3934

Wang W, Andersson M, Iresjö BM et al (2006) Effects of ghrelin on anorexia in tumor-bearing mice with eicosanoid-related cachexia. Int J Oncol 28:1393-1400

Wang W, Bansal S, Falk S et al (2009) Ghrelin protects mice against endotoxemia-induced acute kidney injury. Am J Physiol Renal Physiol 297:F1032-F1037

Wang D, Wang H, Luo P et al (2012) Effects of ghrelin on homocysteine-induced dysfunction and inflammatory response in rat cardiac microvascular endothelial cells. Cell Biol Int 36:511-517

Waseem T, Duxbury M, Ito $\mathrm{H}$ et al (2008) Exogenous ghrelin modulates release of pro-inflammatory and anti-inflammatory cytokines in LPS-stimulated macrophages through distinct signaling pathways. Surgery 143:334-342

Wiedmer P, Nogueiras R, Broglio F et al (2007) Ghrelin, obesity and diabetes. Nat Clin Pract Endocrinol Metab 3:705-712

Wren AM, Seal LJ, Cohen MA et al (2001) Ghrelin enhances appetite and increases food intake in humans. J Clin Endocrinol Metab 86:5992

Wu R, Dong W, Zhou M et al (2005) Ghrelin improves tissue perfusion in severe sepsis via downregulation of endothelin-1. Cardiovasc Res 68:318-326

Wu R, Dong W, Cui X et al (2007a) Ghrelin down-regulates proinflammatory cytokines in sepsis through activation of the vagus nerve. Ann Surg 245:480-486

Wu R, Dong W, Zhou M et al (2007b) Ghrelin attenuates sepsisinduced acute lung injury and mortality in rats. Am J Respir Crit Care Med 176:805-813

Wu R, Zhou M, Das P et al (2007c) Ghrelin inhibits sympathetic nervous activity in sepsis. Am J Physiol Endocrinol Metab 293:E1697-E1702
Wu R, Dong W, Ji Y et al (2008) Orexigenic hormone ghrelin attenuates local and remote organ injury after intestinal ischemia-reperfusion. PLoS ONE 3:e2026

Wu R, Dong W, Qiang X et al (2009) Orexigenic hormone ghrelin ameliorates gut barrier dysfunction in sepsis in rats. Crit Care Med 37:2421-2426

Wu R, Chaung WW, Dong W et al (2012) Ghrelin maintains the cardiovascular stability in severe sepsis. J Surg Res 178:370-377

Yano Y, Toshinai K, Inokuchi T et al (2009) Plasma des-acyl ghrelin, but not plasma HMW adiponectin, is a useful cardiometabolic marker for predicting atherosclerosis in elderly hypertensive patients. Atherosclerosis 204:590-594

Yoshimoto A, Mori K, Sugawara A et al (2002) Plasma ghrelin and desacyl ghrelin concentrations in renal failure. J Am Soc Nephrol 13:2748-2752

Youm YH, Yang H, Sun Y et al (2009) Deficient ghrelin receptormediated signaling compromises thymic stromal cell microenvironment by accelerating thymic adiposity. J Biol Chem 284:7068-7077

Yuan MJ, Huang CX, Tang YH et al (2009) A novel peptide ghrelin inhibits neural remodeling after myocardial infarction in rats. Eur J Pharmacol 618:52-57

Zhan M, Yuan F, Liu H et al (2008) Inhibition of proliferation and apoptosis of vascular smooth muscle cells by ghrelin. Acta Biochim Biophys Sin 40:769-776

Zhang JV, Ren PG, Avsian-Kretchmer O et al (2005) Obestatin, a peptide encoded by the ghrelin gene, opposes ghrelin's effects on food intake. Science 310:996-999

Zhao D, Zhan Y, Zeng H et al (2006) Ghrelin stimulates interleukin-8 gene expression through protein kinase $\mathrm{C}$-mediated $\mathrm{NF}$ kappaB pathway in human colonic epithelial cells. J Cell Biochem 97:1317-1327

Zhou X, Xue C (2009) Ghrelin inhibits the development of acute pancreatitis and nuclear factor kappaB activation in pancreas and liver. Pancreas 38:752-757 